\title{
WORLD EXPERIENCE IN ENSURING SOCIAL AND ECONOMIC SECURITY
}

CShvaiba D., ORCID: 0000-0001-6783-9765, Ph.D., Belarusian Trade Union of Workers of Chemical, Mining and Oil Industries; Belarusian National Technical University, Minsk,Belarus,shvabia@tut.by

\section{МИРОВОЙ ОПЫТ ОБЕСПЕЧЕНИЯ СОЦИАЛЬНО-ЭКОНОМИЧЕСКОЙ БЕЗОПАСНОСТИ}

СШвайба Д. Н., ORCID: 0000-0001-6783-9765, канд. экон. наук, Белорусский профсоюз работников химической, горной и нефтяной отраслей промышленности;

Белорусский национальный технический университет, г. Минск, Беларусь, shvabia@tut.by

Abstract. In the criteria of globalization of the international economy, the role of state regulation in ensuring social and economic security is becoming increasingly prominent. Ensuring the socio-economic security of the state is highly determined by political reasons, the impact of which contains two main vectors: increasing the effectiveness of the internal production process by stimulating the NTP; full assistance to sectors of the economy in foreign markets. The government has an impact on NTP as a direct participation in the $\mathrm{R} \& \mathrm{~d}$ costs, and creation of a positive institutional criteria for acceleration NTP. The role of the government in the development of science and technology as the main factor of economic growth is reflected in the technological policy "Technology for the financial and economic recovery of the country: an innovative vector for the creation of financial power", which is expected to invest in the improvement of technology is considered an important function of the government.

Аннотащия. В критериях глобализации международной экономики роль госрегулирования в обеспечивании социально-экономической безопасности делается все более заметной. Обеспечивание социально-экономической безопасности государства в высочайшей степени определяется политическими причинами, воздействие коих содержит 2 главных вектора: увеличение результативности внутреннего производственного процесса при помощи стимулирования НТП; всемерная помощь секторам экономики на наружных рынках. Правительство оказывает воздействие на НТП как прямым участием в затратах на НИОКР, так и созданием положительных институциональных критериев для ускорения НТП. Роль правительства в развитии науки и технологии как головного фактора роста экономики отражена в технологической политике - «Технологии для финансово-экономического подъема страны: инновационный вектор на создание финансовой мощи», которой ожидается, что инвестирование в совершенствование технологий считается важной функцией правительства.

Keywords: security, socio-economic security; state; society; economic entity; employee; threat; interests; economy, analysis, system, perspective. 
Ключевые слова: защищенность, социально-экономическая безопасность; государство; общество; хозяйствующий субъект; работник; угроза; интересы; экономика, анализ, система, перспектива.

The United States, being far from the main destructive military and political incidents of the XX century, gained a serious superiority for the dynamic development of the economy. But already in the 70-ies of the last century there was a lag in the pace of financial and economic growth of the United States in comparison with Japan and Germany, 90-x with China.

The result of the conditional decline in the performance of the industrial sector in the United States was a decrease in the share of the state in the global export of products of the leading sectors of the processing segment of the economy. At the same time, the us economic segments of a wide range of sectors of the economy began to lose in the competition not only in the world market, but also in the domestic market.

The current financial and economic growth of the United States has been driven by a key upturn in the knowledge-based segment of the economy. The constant rise of super-technological economic entities in recent years has been more than $6 \%$, during this time the rise of other manufacturing sector was equal to $2,4 \%$. Not paying attention to this in recent years, the United States has lost leadership in the global production of a number of knowledge - intensive sectors of the economy: the volume of science - intensive products in the total share of the processing sector amounted to $48 \%$ today (Japan - 70\%, Germany - 50\%), for comparison in 1996, this figure was greater than that of other States - 16\% (Japan - 14\%, Germany - 9\%). The volume of the United States in global exports of information technology equipment was 13\% (Japan - 9,7\%, China $-7,1 \%)$.

Taking into account that these characteristics are determined primarily by investments in $\mathrm{R} \&$ $\mathrm{d}$, we are obliged to indicate that the volume of the United States in the total cost of $\mathrm{R} \& \mathrm{~d}$ in developed countries amounted to $46 \%$. In accordance with this, the United States at different times owned up to 22 of the 50 macro-technologies that form the global market of super-technological products.

This is also the case in other sectors of the economy. Thanks to advanced technology in the United States, for example, from one ton of oil produced 0.5 times more gasoline than in Europe.

The accelerated development of NTP has had a positive impact on both labour productivity and employment structure. Labour productivity is an important indicator of the economic sectors ' performance.

It is necessary to identify a significant role in increasing the efficiency of the production process in the sectors of the venture capital economy, as a subject of the mechanism of ensuring innovative growth of the US economy. Venture capital, especially in the United States, has reached a total of $\$ 19.1$ billion., concentrated mostly in science-intensive sectors of the economy, more effectively ensuring the implementation of scientific inventions. This type of financing to the economy as leasing has also become widespread. In recent years, in the United States, the share of leasing operations in the total investment in the economy is about $30 \%$ (in the EU $-25 \%$ ).

As mentioned earlier, labor affects competitiveness not only as a factor in the production process. The level of development of the labor force to a significant extent determines the quality of demand, which has a special meaning for the progress of the US economy.

The domestic demand of the United States provides an opportunity to successfully develop and consolidate the competitive advantages of industries before entering global markets. Often, due to the high demands on the quality of products of buyers of the state, developed markets for innovative products first appear in the United States, which also puts local producers in a more 
privileged position in the competition with foreign manufacturers.

In the criteria of globalization of the international economy, the role of state regulation in ensuring social and economic security is becoming increasingly prominent. Ensuring the socioeconomic security of the United States is highly determined by political reasons, the impact of which contains two main vectors:

- increase the efficiency of the internal production process through the promotion of NTP;

- comprehensive assistance to the sectors of the economy in the external markets.

The government has an impact on NTP as a direct participation in the R \& $\mathrm{d}$ costs, and creation of a positive institutional criteria for acceleration NTP.

The role of the government in the development of science and technology as head of the growth factor of the economy is reflected in the last technology policy — "Technologies for economic and financial upheaval in the Americas: innovative vector for the creation of financial power", which it is expected that the investment in improving technologies is considered an important function of government.

It should be noted that in recent years, the volume of state expenditure in total $\mathrm{R} \& \mathrm{~d}$ expenditures in the United States is at the level of 55\%, at the expense of which fundamental developments are financed in a key way. The magnitude of the investment amounted to more than $\$$ 90 billion. doll. every month (in 1998 - $\$ 110$ billion). for a year.)

Usually Soedinennye the United States carried out a functional foreign policy is aimed at providing competitiveness of the sectors of the economy. In recent years alone, more than 200 trade and financial agreements have been concluded with other States. The result of this policy was the deepening internationalization and globalization of the American economy, which led to the rise of its interdependence with the global economy. And this state of Affairs not only does not reduce the competitiveness of economic sectors, but also allows the full use of competitive qualities. It is indicative of the fact that, as a result of the Asian crisis in the United States, more than 700 billion flowed from the markets.doll.

To provide assistance to state - owned enterprises directly in the partner States, with the assistance of the United States government, there are business centers, the key task of which is to provide information, legal and other types of support to us corporations.

We will highlight among the main institutional criteria for ensuring the socio-economic security of the United States, the developed system of Universities and research laboratories under them, which provide national values in basic science, which is considered an important condition for the financial and economic stability of the industrialized state, the competitiveness of its sectors of the economy.

A wide, extensive network of funds operating globally to recruit outstanding researchers from various countries to work in the United States is seen as another essential institutional condition for the competitiveness of sectors of the economy. This practice is supported by immigration law, which is characterized by selective action aimed at achieving this goal.

A certain result of the interaction of financial, economic and political aspects of ensuring the socio-economic security of the United States in specific institutional criteria was an increase in the effectiveness of the economy on the basis of innovation.

The development and use of innovative technologies to increase the productivity of money and labor, public funding for most of the $\mathrm{R} \& \mathrm{~d}$ costs, as well as functional foreign economic policy aimed at helping state producers in their competitive struggle in the presence of a developed scientific base, based both on their own scientists and on the recruitment of scientists from other States has made the United States the main donor of science-intensive products in the world.; the 
volume of global exports of high-tech products is more than 2 times the volume of the state in the global exports as a whole.

A significant amount of innovative technologies in the production and export of manufacturing products among the major States is also considered an indicator of the competitiveness of the us economy sectors in the criteria of globalization.

Similarly to the United States, China is now becoming a leading manufacturer of not only the products of the classical sectors of the economy, including metallurgy, but also super-technological products. Export of electronics from China (primarily computer equipment, digital cameras, mobile phones) has already amounted to $\$ 180$ billion., an increase in the year by 1,5 times (exports of similar products of the United States in the same year - 149 billion \$). India is on the same path, increasing exports of software and services.

China, which is developing in accordance with the classical strategy of export-oriented growth for the East Asian States, concentrates on the production of many varieties of industrial products, while their range is expanding every day.

So, if in 1972 Chinese products were on the market of the United States only in $9 \%$ of tendigit commodity items of the nomenclature, then at the moment already in $70 \%$. At the same time, in the production chains for the production of this or that product, China concentrates on the Assembly and finishing stages of production: $2 / 3$ of Chinese imports were intermediate products, while $60 \%$ of exports are final products.

The classical specialization of China was consumer products, the volume of which in exports amounted to $40 \%$, in recent years the state initiates the creation of promising products: their volume in exports increased from $12 \%$ in 1997 to $20 \%$.

The expansion of the range of products manufactured in China can not be displayed on the production specialization of other countries. They are slowly or lose the same economic sectors, or move towards the production of better products, or begin to specialize in the production of individual components or other individual business processes (design, etc.).

As demonstrated by p. SCHOTT, although the correlation between the range of products manufactured in China and the OECD countries is increasing, at the same time increases and the gap between them in the price of a unit of product. According to its interpretation, the latter, reacting to the toughening of competition with China, are obliged to specialize in the production of better products, and thus more expensive [1].

Taking into account that the OECD States can not compete with China on the price of labor, for them it is the only option to save their own niche in the market without lowering wages.

India is one of the few rapidly developing countries that lacks a trade balance and thus relies heavily on domestic consumers. Nevertheless, the main source of progress of this state is considered to be the export - oriented segment of offshore services: programming, accounting, call centers, medical services, etc.the Offer in this segment since 1980 has been growing at an average rate of $7.5 \%$ per year, and employment $-3.6 \%$ per year. The transfer of such services to India also changes the supply structure in other States, in particular in the United States.

It should be noted that due to the large scale of the market for China and India, as well as the fact that these States have been able to dynamically provide training for a significant number of trained engineers, the geography of the placement of research and design structures in the production chains is also changing. More and more applied developments, especially those related to the refinement of products taking into account the specificity of regional demand or the regional organization of the production process, are transferred to the same States where the production itself is cooperated. In the Work of D. Pugi and D. Trefler these innovations are called incremental [2, p. 34]. 
When domestic demand or domestic production in developing countries was small, there was no such shift in the stages of innovation. Today, this practice is becoming more common, and primarily in relation to China, and subsequently to India. Moreover, India has found its own global specialization in global supply, an important share of which (especially offshore programming) is associated with incremental innovation.

The study of the practice of ensuring the socio-economic security of the considered States allows to form separate conclusions $[3 ; 4]$.

In-1, the provision of socio-economic security is associated with measures to strengthen the state financial and economic system to ensure its safe and effective functioning.

This situation is forced by the global financial and economic processes: a significant share of the world market is controlled by transnational companies, the globalization of the international economy is characterized by the concentration and transnationalization of banking structures, this situation is facilitated by the requirements of global organizations (the Berne Union, etc.), combined with the task of reducing financial, economic and monetary risks.

In-2, the socio-economic security of the United States is largely determined by political reasons, the impact of which contains two main vectors:

increasing domestic productivity by encouraging innovation;

all-round (political, diplomatic, military, etc.) assistance to the sectors of the state economy in the domestic and foreign markets (which made it possible, for example, in a short time to pass the mortgage crisis of August 2007).

B-3, a significant degree of Japanese socio-economic security is guaranteed by the following reasons:

advanced technologies of the production process as a result of $\mathrm{R} \& \mathrm{~d}$;

a unique system of labor organization as a technology of human resources management that increases its productivity;

Japanese systems of organization and management of the production process.

In the 4th, China forms the socio-economic security, becoming the largest producer and exporter of not only the products of the classical sectors of the economy, but also supertechnological products. Exports of electronics from China (primarily computer equipment, digital cameras, mobile phones) amounted to $\$ 480$ billion. Per year. India is on this path, increasing the supply of software.

In-5, the increasing importance of ensuring socio-economic security is a natural result of globalization.

In the 6th, the governments of the States, using all possible methods, including direct administrative intervention, actively initiate the increase in the competitiveness of their own producers in the domestic market, supports them in competition in foreign markets, adjusting the impact of the market mechanism taking into account institutional criteria.

At the same time, it is considered common for developed countries in state interference that, in order to ensure socio-economic security, they maintain foreign economic relations that ensure a structure of trade in which exports would be represented by more technological products than imports; and the reverse structure in terms of the movement of capital, which, bringing abroad lowtech enterprises, increases the efficiency of the production process in the state.

\section{References:}

1. Schott, P. K. (2008). The relative sophistication of Chinese exports. Economic policy, 23(53), 6-49. https://doi.org/10.1111/j.1468-0327.2007.00195.x

2. Puga, D., \& Trefler, D. (2005). Wake up and smell the ginseng: The rise of incremental 
innovation in low-wage countries (No. w11571). National Bureau of Economic Research. doi:10.3386/w11571

3. Shvaiba, D. (2019). Dynamic regression models of forecasting indicators of social and economic security. Bulletin of Science and Practice, 5(1). 249-257.

4. Shvaiba, D. (2018). Industry of the Republic of Belarus: problems of social and economic security. Bulletin of Science and Practice, 4(9). 245-252.

\section{Список литературы:}

1. Schott P. K. The relative sophistication of Chinese exports // Economic policy. 2008. V. 23. №53. P. 6-49. https://doi.org/10.1111/j.1468-0327.2007.00195.x

2. Puga D., Trefler D. Wake up and smell the ginseng: The rise of incremental innovation in low-wage countries. National Bureau of Economic Research, 2005. №w11571. DOI: $10.3386 /$ w 11571

3. Shvaiba D. Dynamic regression models of forecasting indicators of social and economic security // Бюллетень науки и практики. 2019. Т. 5. №1. С. 249-257.

4. Shvaiba, D. (2018). Industry of the Republic of Belarus: problems of social and economic security // Бюллетень науки и практики. Т. 4. №9. С. 245-252.

Работа поступила

в редакцию 26.07.2019 2.
Принята к публикациии

29.07.2019 2.

Ссылка для циитирования:

Shvaiba D. World Experience in Ensuring Social and Economic Security // Бюллетень науки и практики. 2019. Т. 5. №9. С. 250-255. https://doi.org/10.33619/2414-2948/46/31

Cite as (APA):

Shvaiba, D. (2019). World Experience in Ensuring Social and Economic Security. Bulletin of Science and Practice, 5(9), 250-255. https://doi.org/10.33619/2414-2948/46/31 (in Russian). 